\title{
Gender, Education and Marital Status as Determinants of Leadership Styles among Pastoral Leaders
}

\author{
Uzonwanne, C. Francis, Ph.D; Nwanzu, Lucky.Chiyem, Ph.D \\ Department of Behavioural Studies (Psychology), Redeemer's University, Ede, Osun State, Nigeria \\ Department of Psychology, Delta State University, Abraka, Nigeria
}

\begin{abstract}
This study assessesthe influence of gender, education and marital status on transformational, transactional, and laissez faire leadership styles among pastoral leaders in churches around the metropolis of Abuja, Nigeria. Design of this study was a cross-sectional survey design and data were collected with The Multifactor Leadership Questionnaire (MLQ). One hundred and seventy (99 males; 71 females) pastoral leadersin Abuja, Nigeria selected with incidental random sampling technique, provided the data that were analyzed. Multivarate analysis of variance on the data revealedno significant gender difference in leadership styles, $F(4,165)$ $=1.574, P>.05)$, no significant marital status difference in leadership styles, $F(8,328)=1.373, P>.05$, and $a$ significant educational level difference in leadership styles, $F(16,496)=1.508, P<.05)$ among pastoral leaders. It was concluded that while education determines pastoral leaders' leadership style; gender and marital status do not. It is recommended that future research adopt mixed method in data collection.
\end{abstract}

Keywords- Gender, educational, marital status, transformational leadership, transactional leadership, laissez faire leadership and pastoral leaders.

\section{INTRODUCTION}

Leadership style is a concept that has caught the attention of both researchers and professionals globally. Leadership refers to the ability to lead, direct and organize a group; an individual impacts a gathering of people to accomplish a shared objective (Abasilim, 2014; Northouse, 2004)as it is with the case of Pastors andleaders in organizations of worship. Leadership is a dynamic process at work in a group whereby one individual over a particular period of time, and in a particular context influences the other group members to commit themselves freely to the achievement of group tasks or goals (Cole, 2002).Organizations of worship, like any other organization, are goal driven and as those goals are accomplished, others manifest and are invariably pursued. Leadership style has been identified as one of the factors that can enhance or impede organizational performance (Abasilim, 2014) as it relates with achieving existing and future goals. Different cultures around the world give accounts of renowned individuals who were brave, spirited, crafty, and valiant; some individuals even exhibited a combination of these qualities. Charismatic and vibrant leaders are known to command great worship organizations, kingdoms, establishments, and civilizations. Leaders who manage vital spiritual organizationsare the focus of this study as the goals that the organizations pursue are imperative to humanity as a whole. Aldoory and Toth (2004) report that as the body of knowledge on leadership grows in management, business and marketing research, debate about leadership styles, skills and effectiveness also grows. Much of this debate centers on gender and other demographic differences in leadership styles. Owing to the importance of spiritual organizational leadership to human existence, there is a need to increase understanding and knowledge on the leadership of spiritual organizations globally; this is expected therefore, to eventually increase acquisition of skills and effectiveness among spiritual leaders. Social scientists have examined spiritual leaders as well as other leaders in research, to classify individual traits, capabilities, and behaviours that are peculiar to spiritual leaders and other social factors that exert influence on leadership decisions and directions (Thompson, 2000).

In non-profit organizations like churches, leadership effectiveness by pastoral leaders is measured by the outcome of physical and character transformation resulting from the input of admonition, advise, counseling, and preaching of the word of God in general. As Goleman (2000) proposes, "a pioneer solitary occupation of a leader is to get results" p:137. Nonetheless, successful leadership can be delineated by more than authoritative results. 
Leadership adequacy can likewise be clarified as decision making. Herbert (1957) affirms that decision making "overruns" leadership and that "a general theory of association must incorporate rule that will protect successful activity." For all intents and purposes, leadership is a movement of decisions (i.e. activities and inactions) stretching out from the little and evidently immaterial to the immense and obviously inauspicious. What leaders choose and how they choose it are imperative determinants of leader's viability. A deeper understanding into leadership styles used by spiritual leaders could help to broaden general outlook on how it affects communication between the nleaders and subordinates. The way of pastoral leadership is clearly a noteworthy issue for theological colleges whose main purpose behind presence incorporates the preparing of clergy for the congregation. There is no one right way to lead, therefore various Christian religious leaders deal with the same situation with different approaches depending on their personality, strengths, emotional intelligence and level of knowledge about that situation. A leader's style of leadership also infringes on the likelihood of situational outcomes and follower's action and reaction in the religious sector.

According to Burns (1978) "Leadership is one of the most observed and least understood phenomena on earth." The lack of understanding of leadership and leadership styles even from an African perspective poses a problem on its own. Demographic variables such as gender, age, and educational level have been used to predict many leadership behaviors (BarbutuJr, Fritz, Matkin, and Marx, 2007) but a dearth of literature still existson issue of demographic characteristics and leadership styles, particularly in the present research location. This is especially true among pastoral leaders, a population that should be heavily studied, given their strategic position in nation building and sustainable human capital development. Again, aside a dearth of existing literature on demographic characteristics and leadership stylesaamong the population of interest, the results from the extant studies are largely contradictory. According to BarbutuJr, et. al(2007)for every study that has shown gender differences in transformational leadership behaviours there is another that shows no differences. Church associations in the need to make positive enhancements and to produce fruitful and successful progressive environments, while adequately changing the lives and characters of their adherents, ought to consider giving more need to upgrading the leadership abilities in their places of worship.In the bid to better understand the concept of leadership styles, it is imperative to further examine how these demographic variables influence the identified leadership styles among actual leaders in Nigerian Churches. This study therefore examines some gender, educational levels and marital status, as possible correlatesof transformational, transactional and Laissez Faire leadership styles among pastoral leadersin Abuja, Nigeria. The purpose of this study is to provide information that could contribute to effective training of pastoral leaders on leadership styles.

The role of leadership in an environment rife with the need for transformational change cannot be debated. Despite evolutions and structural redefinitions in the organization and leadership of Churches, leadership yet remains the only avenue by which the goals of the Church can be achieved. Nigeria as a nation still struggles in the doldrums of underdevelopment and desperately in need of effective and dependable leadership. Corruption tops the list of factors positioning the nation in an absence of decorum. Pastoral leadership constitutes direct contact to the citizenry and therefore a foremost forum to reach Nigerians and transform their minds from corruption and general decadence. It has however been established that leadership remains one of the least understood concepts despite plethora of research available to achieve this. It is therefore necessary to continue to approach the topic of leadership from every angle that will facilitate better understanding, especially in the spiritual and religious context.

\section{Transformational Leadership}

Transactional leadership takes precedence when there is a trade between individuals which can be monetary, political or mental in nature. The relationship between the leader and the supporter is absolutely in view of haggling and it doesn't go past this. Be that as it may, transformational leadership happens when the leader and the devotee lifts each other to more elevated amounts of inspiration and ethical quality. Carlson (1996) calls attention to Burns, who felt that leadership speculations created up to the mid-seventies were missing moral/moral measurements so he explained on his trade (transactional) theory which keeps up the fact that devotees assume a vital part in the meaning of leadership. This theory is comprised of force relations and involves dealing, exchanging and trade off among leaders and supporters.

Abasalim (2014) remarked that the goal of transformational leadership is to transform people and organizations. In a literal sense to change people's mind and heart: enlarge vision, insight, and understanding; clarify purposes; make behavior congruent with beliefs, principles, or values; and 
bring about changes that are permanent, self- perpetuating, and momentum building (Masi, 2008). According to Burns (1978), who first introduced the concept of transforming leadership, it is a process in which "leaders and followers help each other to advance to a higher level of morale and motivation". Burns (1978) noted to the difficulty in differentiation between management and leadership and claimed that the differences are in characteristics and behaviors. Transformational leadership is however based on the leader's personality, traits and ability to make a change through example, articulation of an energizing vision and challenging goals (Burns, 1978).Another researcher, Bass (1985), extended the work of Burns (1978) by explaining the psychological mechanisms that underlie transforming and transactional leadership. Bass however used the term "transformational" instead of "transforming." Bass also added to the initial concepts of Burns (1978) to help explain how transformational leadership could be measured, as well as how it impacts follower motivation and performance. Transformational leaders urge supporters to go past their self-interests and be worried about their association, as they help devotees to acknowledge and build up their potential (Bass, 1985). According to Bass and Avolio (1997), these leaders distinguish the necessities of their adherents and after that consider those requirements to improve advancement, while they accumulate their supporters around a typical reason, mission or vision and give a feeling of reason and future heading. Besides, they go about as good examples for their devotees and urge them to question issues that underlie fundamental suppositions from alternate points of view; they need their supporters to see challenges as circumstances and they collaborate with them to raise desires, needs, capacities, and good character (Bass \&Avolio, 1997).

The extent to which a leader is transformational is measured first, in terms of his influence on the followers.Bass (1985) introduced a full range of transformational leadership which includes the four elements:

(1) Individualized Consideration: This is the degree to which the leader attends to each follower's needs, acts as a mentor or coach to the follower and listens to the follower's concerns and needs. The leader gives empathy and support, keeps communication open and places challenges before the followers. This also encompasses the need for respect and celebration of contribution that each follower can make to the team. The followers have a will and aspirations for self-development and have intrinsic motivation for their tasks.
1 Intellectual Stimulation: This is the degree to which the leader challenges assumptions, takes risks and solicits followers' ideas. Leaders with this style stimulate and encourage creativity in their followers. They nurture and develop people who think independently. For such a leader, learning is a value and unexpected situations are seen as opportunities to learn. The followers ask questions, think deeply about things and figure out better ways to execute their tasks.

2 Inspirational Motivation: This is the degree to which the leader articulates a vision that is appealing and inspiring to followers. Leaders with inspirational motivation challenge followers with high standards, communicate optimism about future goals, and provide meaning for the task at hand. Followers need to have a strong sense of purpose if they are to be motivated to act. Purpose and meaning provide the energy that drives a group forward. The visionary aspects of leadership are supported by communication skills that make the vision understandable, precise, powerful and engaging. The followers are willing to invest more effort in the tasks they are encouraged and optimistic about the future and believe in their abilities.

3 Idealized Influence - This provides a role model for high ethical behavior, instills pride, gains respect and trust.

\section{Transactional leadership}

Transactional leadership style involve an exchange process based on the fulfillment of contractual obligation and is typically represented as setting objectives and monitoring and controlling outcomes. Transactional leadership is a style of leadership in which the leader promotes compliance of his followers through both rewards and punishments. Unlike Transformational leadership, leaders using the transactional approach are not looking to change the future; they are looking to merely keep things the same. These leaders pay attention to followers' work in order to find faults and deviations. This type of leadership is effective in crisis and emergency situations, as well as when projects need to be carried out in a specific fashion. According toBass (1985) the two dimensions of transactional leadership are:

1. Contingent rewards: This refers to those aspects of the leadership in which leaders clarify goals, talk about expected behaviour and accomplishments, 
and reward subordinates for expected level of performance.

2. Management by exception: This refers to the behaviour of leaders who often engage in corrective transactions with followers. The process of searching for mistakes can be passive, waiting for errors to occur, or active, when leaders closely examine work processes so that mistakes can be prevented and corrected (Pastor \& Mayo, 2006).

\section{Laissez Faire Leadership}

Free enterprise (laissez-fairre) leadership is identified when leaders are hands-off and permit followers to settle on their choices. With this style, advancement is completely dictated by group members. Productivity in accomplishing objectives, strategies, and working techniques, leaders once in a while intercede. Free enterprise style is depicted as the best style, particularly where devotees are mature, full grown and exceptionally energetic (Hackman \& Johnson, 2009). Free enterprise leadership style permits complete flexibility to cooperative choice without the leader's investment, accordingly, subordinates are allowed to do what they like (Hackman \& Johnson, 2009). The significant part of the leader is overwhelmingly to give resources. The leader does not meddle with or take an interest over the span of occasions controlled by the gathering (Talbert \&Milbrey, 1994).

\section{Gender and Leadership Styles}

Considerable research has been carried out on gender differences in leadership styles more than other demographic factors. As more women in industrialized nations enter leadership roles in society, the possibility that they might carry out leadership roles differently than men attracts increasing attention (Miller, Taylor, \& Buck, 1991). Eagly and Johnson (1990) in a an attempt to discover gender differences in leadership styles, found that women were more participative, or democratic than men leaders, while men were more directive or autocratic than women. Females also showed more concern with the maintenance of inter-personal relationships than men who displayed more task-oriented behaviours. Eagly and Johnson (1990) however concluded that the widely accepted belief that men and women lead in the same way should be "very substantially revised" (Druskat, 1994). Another study by Rosener (1990) also validated Eagly and Johnson's findings while pointing out that women's leadership and influence styles are consistent with transformational leadership while the men's styles are consistent with transactional leadership style. In yet another study by Komives (1991), results revealed that both men and women rated themselves as using more transformational than transactional leadership behaviours (Druskat, 1994). Their perceptions of what constituted transformational leadership differed sharply (Druskat, 1994). While women leaders considered their relational achievement styles to be transformational, male leaders felt that their power-direct styles were considered to be transformational. Subordinates rating the male and female leaders however did not rate either of them as being transformational leaders (Komives, 1991). In Druskat (1994)'s study of administrative and religious leaders, there was a higher prevalence of transformational leadership than transactional leadership styles. Women were however rated to exhibit significantly more transformational leadership behaviours than men, while men were rated as exhibiting significantly more transactional leadership behaviours than women (Druskat, 1994). Rosener (1990) also found that women leaders exhibited an interactive style of leadership conducive to transformational leadership while men leaders exhibited a directive style more conducive to transactional leadership style. BarbutuJr, Fritz, Matkin and Marx (2007) however found that gender did not influence transactional and transformational leadership. These varying sets of findings in literature facilitates the current research to determine gender as a determinant of leadership style among religious leaders in Nigeria

\section{Educational Qualification and Leadership Styles}

Not many studies covering the influence of educational qualification and marital status on leadership style exist. BarbutuJr, Fritz, Matkin and Marx (2007) found that the leader's level of education produced a significant main effect on followers' perceptions of transactional and/ or transformational behaviors. In the study, significant differences were found among educational level groups for individualized consideration; those leaders who had earned an advanced degree exhibited the highest rating level in this subscale and leaders' educational level showed no main effect on ratings of influence tactics.Vecchio and Boatwright (2002) found that employees with higher levels of education and greater job tenure expressed less preference for leader structuring (task-oriented behaviors). BarbutuJret al (2007) reports that a few studies included gender, age, and education as demographic variables in their examination of leadership styles and these studies produced mixed findings on the significance of the effects of these variables on leadership style (BarbutuJr et al, 2007). Gender, age, and education all were found to predict 
a significant magnitude of team effectiveness (Taylor, 1998).Kotur and Anbazhagan (2014) studied the influence of education and work experience on leadership styles of workers, in the Chittoor Sugar factory in Indian and reported significant difference.

\section{Marital Status and Leadership Styles}

A few scholars have examined the influence of marital status on leadership styles. Mohammed, Othman, and D'Silva, (2012)examined social demographic factors that the influence transformational leadership styles among top management in selected organizations in Malaysia with 379 participants and reported no significant gender, race, marital status and educational level difference transformational leadership styles.Koc, Kiliclar, and Yazicioglu (2013) analyze leadership styles of 771 Turkish managers from public and private sectors in the scope of the Blake and Mouton's (1964) managerial grid and observed, among others that the management styles of managers differ on managerial grid diagram in term of marital status. In other words managerial styles of managers differ in accordance with their marriage position. The married managers' means are higher than single managers' in managerial diagram. Otieno (2016) examined the influence of demographic factors on women's participation in political leadership in Rongo Constituency, Migori County, Kenyawith 60 women concluded that women's marital status and educational level influence their participation in political leadership, however, analysis of data collected for the study was sole descriptive. Kaur (2012) examined the influence of transformational and transactional leadership behaviour in selected public and private sector banks in Chandigarh and reported that marital status and work experience influence employees perception of leadership behaviour, but gender, age, qualification and level of management did not.Ortyoyande, (2012) examined the relationship between demographic factors and leader behaviour department chair persons of colleges of education in Michigan with 126 participants and reported that age, gender, educational background, marital status, social class, career path, professional membership, and publication do not have significant relationship with leader behaviour. However, a significant positive relationship was reported between leadership experience and leader behaviour.

\section{Hypotheses}

1 There is a significant gender difference in transformational, transactional, and laissez faire leadership styles among pastoral leaders.
2 There is a significant educational level difference in transformational, transactional, and laissez faire leadership styles among pastoral leaders.

3 There is a significant marital status difference in transformational, transactional, and laissez faire leadership styles among pastoral leaders.

\section{Research Design}

\section{METHOD}

This study adopted a cross-sectional survey research design. The independent variables were gender, marital status and educational level, while the dependent variables were transformational, transactional and laissez faire leadership styles.

\section{Research Population/Sampling}

The population of this study was pastoral leaders, which comprise general overseers, deputy general overseers, senior pastors and heads of Christian ministries in Abuja, Nigeria. An incidental sampling method was used to draw 200 samples from the population. Data provided by 99 males, 71 females were used for analysis.

\section{Research Instrument}

A questionnaire was used to collect data from the selected respondents. A section of the questionnaire issued to the respondents collected demographic variables like age, marital status, education and so on. The second part of the questionnaire was used to collect data on the leadership styles of the respondents.

The Multifactor Leadership Questionnaire, Form 6-S; was adopted for the study. The scale was developed by Bass and Avolio (1995) and it comprises 21 items. Three dimensions of leadership styles (transformational, transactional and laissez-faire) were operationalized in the questionnaire. Transformational leadership has four dimensions- idealized influence, inspirational motivation, intellectual stimulation and personal and individual attention. Each of the dimensions has 3 items. Transactional leadership style has two dimensionscontingent reward and management-by -exception. And each dimension has three items. Laissez-faire has a dimension with three items. This instrument is the most frequently used, well researched and validated leadership instrument in the world (Tejeda, 2001). It has been applied to a wide range of organizational settings as well as leaders in different cultures (Bass, 1998).

Substantive evidence from a number of studies conducted by Tejeda (2001), Avolio and Bass (1999) showed that the MLQ is indeed a valid instrument across a number of validity types. Tejeda (2001) found firstly, that a reduced 
set of items from the MLQ appeared to show preliminary evidence of predictive and construct validity; secondly, the transformational subscales or items were highly intercorrelated in support of convergent validity; and thirdly, the transformational leadership scales were negatively related to both management-by-exception subscales and laissezfaire leadership, providing support for discriminant validity.However, for the present study, reliability coefficients of $.79, .80,81,78,80$ and 82 were obtained for Idealized influence, Individualized Consideration, Inspirational Motivation, Intellectual Stimulation, Contingent Rewards, and Management-by-Exception subscales respectively. Responses were recorded on 5-point Likert scale, 0 "not at all", 1 "once in a while", 2 "sometimes", 3 "fairly often" and 4 "frequently, if not always".

\section{Data analysis}

The statistical test of Multiple Analysis of Variance (MANOVA) was utilized for testing the stated hypotheses. MANOVA was appropriate for the test of hypotheses as the dependent variable was treated at three levels (transformational, transactional and laissez-faire). The data were analyzed with the aid of the Statistical Package for Social Sciences (SPSS) version 22.

FINDINGS

\section{Hypothesis 1}

There is a significant gender difference in transformational, transactional, and laissez faire leadership styles among pastoral leaders.

\section{Result}

For hypothesis one, descriptive statistics revealed that males mean score on the composite analysis was 66.25 (SD, 8.31), while that of females was 64.85 (SD, 8.82). For the dimensional analysis (i.e. transformational, transactional and laissez faire) males mean scores were 38.22 (SD, 5.74), 19.30 (SD, 2.57), and 8.72 (SD 1.74), while that of females were 37.94 (SD, 6.09), 18.69 (SD, 2.54), and 8.87 (SD, $1.80)$ respectively.

A Multiple Analysis of Variance (MANOVA) statistical analysis tool was used to test the hypothesis. Table 1 shows the multivariate analysis of variance of gender on transformational, transactional, and laissez faire leadership styles of pastoral leaders. The result indicates no statistically significant gender difference in transformational, transactional, and laissez faire leadership styles among pastoral leaders, $\mathrm{F}(4,165)=1.574, \mathrm{p}>$ $.05(0.184)$; Wilk's Lambda $=0.963$, Partial Eta Squared $\eta^{2}$ $=.037$. Post Hoc test wasnot available because the independent variable, gender, had only two levels.Therefore, hypothesis 1 was rejected.

Table.1: Multiple analysis of variance on gender differences in transformational, transactional, and laissez faire leadership styles among pastoral leaders

\begin{tabular}{llllll}
\hline EFFECT & Value & Df & Power & F & P \\
\hline Gender & .963 & 4.000 & .478 & 1.574 & .184 \\
Wilk's Lambda & & & & & \\
\hline
\end{tabular}

\section{Hypothesis 2}

There is a significant educational level difference in transformational, transactional, and laissez faire leadership styles among pastoral leaders.

\section{Result}

For hypothesis two, descriptive statistics revealed that for the composite analysis, the mean scores for WAEC/SSCE, OND, HND/BScand Master's/Ph.Dcertificate holders are 64.79 (SD, 6.14), 62.04 (SD, 10.13), 65.73 (SD, 8.75), and 67.98 (SD, 7.45) respectively.For the analysis of transformational leadership style,WAEC/SSCE, OND, HND/BSc and Master's/Ph.D mean scores were 36.58 (SD, 4.10), 35.29 (SD, 6.35), 38.57 (SD 6.25) and 39.44 (SD 4.94) respectively. For the analysis of transactional leadership style, WAEC/SSCE, OND, HND/BSc and
Master's/Ph.D mean scores were 19.16 (SD, 2.22), 18.08 (SD, 2.65), 18.87 (SD 2.60) and 19.88 (SD 2.39) respectively. For the analysis of laissez faire leadership style, WAEC/SSCE, OND, HND/BSc and Master's/Ph.D mean scores were 9.05 (SD, 1.51), 8.25 (SD, 2.03), 8.60 (SD 1.63) and 9.30 (SD 1.85) respectively.

Table 2 shows the multivariate analysis of variance of educational qualifications on transformational, transactional, and laissez faire leadership styles of pastoral leaders. The result indicates statistically significant educational qualification difference in transformational, transactional, and laissez faire leadership styles among pastoral leaders, $\mathrm{F}(16,496)=1.508, \mathrm{p}<.05(0.42)$; Wilk's Lambda $=0.855$, Partial Eta Squared $\eta 2=.046$. Therefore, hypothesis 2 was accepted. 
Table.2: Multiple analysis of variance on educational level differences in transformational, transactional, and laissez faire leadership styles of pastoral leaders

\begin{tabular}{llllll}
\hline EFFECT & Value & Df & Power & F & P \\
\hline $\begin{array}{l}\text { Gender } \\
\text { Wilk’s Lambda }\end{array}$ & .885 & 12.000 & .882 & 1.782 & .042
\end{tabular}

Table 3 onpost hoc test analysis show a significant difference in transformational leadership of Masters/Ph. $\mathrm{D}$ degree holders $(\mathrm{n}=$ 43 , mean $=39.44, \mathrm{SD}=4.94)$ and OND holders $(\mathrm{n}=19$. Mean $=35.29, \mathrm{SD}=6.35)(\mathrm{p}=0.030),<.05$.

Table.3: Post hoc multivariate analysis on educational level differences in transformational, transactional, and laissez faire leadership styles of pastoral leaders

\begin{tabular}{|c|c|c|c|c|c|c|}
\hline SOURCE & DV & $\mathrm{SS}$ & DF & MS & $\mathrm{F}$ & $\mathrm{P}$ \\
\hline & Transformational Leadership & 360.49 & $\underline{4}$ & 90.12 & 2.72 & .030 \\
\hline \multirow[t]{3}{*}{ Education } & Transactional Leadership & 59.30 & $\underline{4}$ & 14.83 & 2.33 & .058 \\
\hline & Laissez Faire Leadership & 22.68 & 4 & 5.67 & 1.87 & .118 \\
\hline & Leadership (MLQ) & 568.47 & 4 & 14.12 & 2.00 & .097 \\
\hline
\end{tabular}

\section{Hypothesis 3}

There is a significant marital status difference in transformational, transactional, and laissez faire leadership styles among pastoral leaders.

\section{Result}

For hypothesis three, descriptive statistics revealed that for the composite analysis, the mean scores for married, single and divorced are 65.48 (SD, 8.47), 65.55 (SD, 8.67) and 68.87 (SD, 8.44) respectively. For the analysis of transformational leadership style, the mean scores for married, single and devoiced were 38.33 (SD, 5.96), 37.57 (SD, 5.92) and39.75 (SD 4.23) respectively. For the analysis of transactional leadership style, the mean scores for married, single, and divorced were 18.87 (SD, 2.55), 19.20 (SD, 2.63) and 19.87 (SD 2.10) respectively. For the analysis of laissez faire leadership style, the mean scores for married, single and divorced were 8.66 (SD, 1.65), 8.76 (SD, 1.88) and 10.37 (SD 1.18) respectively. Table 4 shows the multivariate analysis of variance of marital status on transformational, transactional, and laissez faire leadership styles among pastoral leaders in Abuja. The result indicates no statistically significant marital status difference in transformational, transactional, and laissez faire leadership styles among pastoral leaders, $F(8,328)=1.373, p>.05$; Wilk's Lambda $=0.936$, Partial Eta Squared $\eta^{2}=.032$. Therefore, hypothesis 3 was rejected.

Table.4: Multiple analysis of variance on marital status differences in transformational, transactional, and laissez faire leadership styles of pastoral leaders.

\begin{tabular}{llllll}
\hline EFFECT & Value & Df & Power & F & P \\
\hline $\begin{array}{l}\text { Gender } \\
\text { Wilk's Lambda }\end{array}$ & .936 & 8.000 & .625 & 1.373 & .207
\end{tabular}

Post Hoc test analysis, as indicated in Table 5, however shows a significantdifference in the laissez faire leadership of divorced pastors $(\mathrm{n}=8$. Mean $=10.37, \mathrm{SD}=1.18)(\mathrm{p}=$ $0.022), \alpha=.05$ and married pastors $(\mathrm{n}=96$, mean $=8.66$,
SD = 1.65). Post Hoc analysis also show a significant difference in the laissez faire leadership of divorced pastors $(\mathrm{n}=8$. Mean $=10.37, \mathrm{SD}=1.18)(\mathrm{p}=0.022), \alpha=.05$ and single pastors $(n=66$, mean $=8.76, S D=1.88)$. 
Table.5: Multiple analysis of variance on marital status differences in transformational, transactional, and laissez faire leadership styles of pastoral leaders

\begin{tabular}{lllllll}
\hline SOURCE & DV & SS & DF & MS & F & P \\
\hline \multirow{3}{*}{ Marital Status } & Transformational Leadership & 45.14 & $\underline{2}$ & 22.57 & .652 & .523 \\
& Transactional Leadership & 9.80 & $\underline{2}$ & 4.91 & .746 & .476 \\
& Laissez Faire Leadership & 21.61 & 2 & 10.81 & 3.60 & .029 \\
& Leadership (MLQ) & 86.33 & 2 & 43.16 & .590 & .555 \\
\hline
\end{tabular}

\section{DISCUSSION}

This study assesses the influence of gender, education and marital status on transformational, transactional, and laissez faire leadership styles among pastoral leaders in churches around the metropolis of Abuja, Nigeria. Hypothesis 1 which states that there is a significant gender difference in transformational, transactional and laissez faire leadership styles among pastoral leaders was not supported. This is unexpected and contrary to a few extant studies. For instance, Eagly and Johnson (1990) observed that women were more participative or democratic than men leaders, while men were more directive or autocratic than women. Rosener (1990) reported that women's leadership and influence styles are consistent with transformational leadership while the men's styles are consistent with transactional leadership style. Hypothesis 2 which states that there is a significant educational level difference in transformational, transactional and laissez faire leadership styles among pastoral leaders was accepted. This finding is in congruent with the extant literature. Taylor (1998) reported that gender, age and education predict a significant magnitude of team effectiveness. Kotur and Anbazhagan (2014) reported significant difference in males and females leadership styles. Hypothesis three which states that there is a significant marital status difference in transformational, transactional and laissez faire leadership styles among pastoral leaders was rejected. This is also unexpected and contrary to a few extant studies. For instance, Koc, Kiliclar, and Yazicioglu (2013) observed, among others that the management styles of managers differ on managerial grid diagram in term of marital status. However, some studies in the literature were in congruence with the finding of the present study. Ortyoyande, (2012) examined the relationship between demographic factors and leader behaviour of department chair persons of colleges of education in Michigan with 126 participants and reported that marital status does not have significant relationship with leader behaviour.Gender, education and marital status havepartial effect squared $\left(\mathrm{eta}^{2}\right)$ of $.037, .046$ and .032 respectively on leadership styles among pastoral leaders. This indicates that the three variables individually have between small and medium impact on leadership styles among pastoral leaders. A plausible explanation for the findings of the present study on gender, marital status and leadership styles of pastoral leaders is in the influence followers do have on their leaders. Leaders do not only lead on the bases of their characteristics, but also on the direct and indirect influence the followers. Followers influence on leaders' behaviour may neutralize the influence leaders' characteristics, such as gender and marital status have on leadership styles. A plausible explanation for the finding of the present study on education could be in the difference education make in people life. Different levels of education have different level of impact on people's behaviour, and leadership styles are behaviour.

Descriptive statistics show that Master's degree holders manifest transformational leadership above other educational levels. Divorced pastors also manifested significantly higher levels of laissez faire leadership than married and single pastors. Education is a catalyst for transformation in pastoral leader as an individual and then to the individuals they are giving so much to transform. An enlightened mind is most likely to enlighten minds. Further education has shown from this study to enhance transformation in the leadership style of those who have strived for that goal. Transformational leadership happens when the leader and the devotee lifts each other to more elevated amounts of inspiration and ethical quality. This process of course is initiated and maintained by the leader. A transactional environment may be the case in many religious/spiritual organizations. There is an apparent focus on transactional deals more than transformational processes. Devotees who perform acts of giving and other loyalty facilitated activities remarkably over the other devotees, have access to the leader and whatever the leader offers, basedon the degree to which they perform these acts. Hence, the vertical dyad linkage model or the LeaderMember Exchange comes to play. 
Leader-Member Exchange model states that the types of one-on-one, or dyadic, relationships that develop between the leader and each follower will be somewhat different. In such environments, the leader tends to develop better relationships with a few subordinate (the in-group), while the rest receive less attention or concern from the leader (out-group). The character of the leader-member exchange can range from low quality, in which the leader has a negative image of the subordinate and the subordinate does not respect or trust the leader, to high quality, in which the leader has a positive view of the worker or member and the individual feels that the leader is supportive and provides encouragement. Of course, such differences affect important outcomes such as work performance, devotee loyalty and attendance, and spiritual satisfaction.

The study showed that laissez faire leadership style was a significant determinant among divorced pastors. The implication could either be that laissez faire style is a catalyst to divorce or a divorce could be catalyst to eventual learned laissez faire leadership style. Either could be argued at length, but since behaviour and hence leadership style could be learned and unlearned, either argument could hold sway. Marriage is a life-long institution and the Christian faith frowns strongly at the demise of this institution. In actual fact, the Christian faith holds that a major qualification for pastoral leadership lies in the ability to maintain a marriage with one wife and hence a family in good light,and this being pre-requisite to extending such towards the Church family. Laissez Faire leadership style, despite its documented advantages, may be not be effective for leading a family, especially families under strict scrutiny like that of the pastoral leadership's family. Further studies can suggestively look more into leadership styles and Christian family leadership outcomes. Owing to an apparent dearth of literature surrounding the influence of marital status on leadership styles, this discussion does not include previously reviewed literature on the topic; hence the usefulness of the findings from this study on the current body of knowledge relating to this variables.

\section{CONCLUSION AND RECOMMENDATIONS}

On the bases of findings from this study the following conclusions could be made. First, gender does not determine whether a pastoral leader adopts transformational, transactional or Laissez leadership style. Second, education determines whether pastoral leader adopts transformational, transactional or Laissez leadership style. Transformational leadership style is adopted most by Master's degree holders.Third, marital status does not determine whether a pastoral leader adopts transformational, transactional or Laissez leadership style. Fourth, divorced pastors have higher level of laissez faire leadership than married or single pastors. And fifth, on the bases of the observed effect size, gender, education and marital status separately has effect sizes of practical importance.

It is recommended therefore that the administration of Church ministry leaders in Nigeria should take into consideration the findings of this study as leaders are being prepared on a constant basis for the spiritual and administrative challenges they face. Leaders must continue to be provided with ongoing training on cutting edge best practices in introducing and infusing transformational leadership processes to governance. These training should be offered to all participants and candidates alike, despite their gender orientations, educational qualification (as long as it meets the minimum required) and marital status. In recruiting also, it is recommended that the future recruitment should be done without much concern as to gender orientations, special consideration to educational qualification and careful consideration to marital status. Previous studies have shown that females may be more prone to lean towards transformational behaviours, hence the tendency to laden certain counseling and human capacity building initiatives like marriage and homekeeping programmesto female leadership. It is recommended however that regardless of the initiative, gender should not be an issue in making such considerations.

The present study has some limitations which point to directions for future research. Data for this study were drawn from only one metropolis in Nigeria; this could have implication for result generalization. Therefore, future studies should collect data from more location to achieve representativeness. Self-report questionnaire was the sole tool for data collection. There could be issue of social desirability bias and common method variance in data collection. Future studies should adopt triangulation approach in data collection. The present study was crosssectional, which does not identify cause-effect relationship. Future studies should explore quasi-experiment and longitudinal study to enable causal interpretation. As identifiable in the literature, aside demographic characteristics other factors such as personality determine leadership styles, therefore future studies should use structural equation modeling in order to capture more variables in a single study. 


\section{REFERENCES}

[1] Abasilim, U. D. (2014). Transformational leadership style and its relationship with organizational performance in Nigerian work context: A review. IOSR Journal of Business and Management (IOSRJBM), 16 (9), 01-05.

[2] Aldoory, L., \&Toth, E. (2004). Leadership and gender in public relations: Perceived effectiveness of transformational and transactional leadership style. Journal of Public Relations Research, 16(2), 157183.

[3] BarbutuJr, J.E., Fritz, S., Matkin, G.S.,\& Marx, D.B. (2007).Effects of gender, education, and age upon leaders' use of influence tactics and full range leadership behaviors. Sex Roles 56, 71-83.

[4] Bass, B. M,(1985). Leadership and performance, New.York: Free Press.

[5] Bass, M., \&Avolio, B. (1992). Developing transformational leader ship: 1992 and beyond. Journal of European Industrial Training, 14, 21-37.

[6] Bass, B. M. \&Avolio, B. J. (1997).Full range leadership development: Manual for the multifactor leadership questionnaire, Thousand Oaks,CA: Mind Garden.

[7] Burns, J.M, (1978). Leadership, New York: Harper and Row.

[8] Carlson, R.V. (1996). Reframing and reform. New York: Longman.

[9] Cole, G.A. (2002) Personnel and human resource management.(5thed). London: Continuum Published.

[10] Druskat, V.U. (1994). Gender and leadership style: Transformational and transactional leadership in the Roman Catholic Church. Leadership Quarterly, 5(2), 99-119.

[11] Eagly, A. H. and Johnson, B. T. (1990). Gender and leadership style: A meta-analysis. Psychological Bulletin, 108(2), 233-256

[12] Goleman, D (2000March-April). Leadership that gets results.Harvard Business Review, 1- 15.

[13] Hackman, M. Z., \& Johnson, C. E. (2009).Leadership: A communication perspective (5th ed.). Long Grove, IL: Waveland Press.

[14]Herbert, S. (1957). A behavioral model of rational choice in models of man, social and rational: mathematical essays on rational human behavior in a social setting. New York: Wiley.

[15] Hoy, W. K., \& Tarter, C. J. (2004). Organizational justice in schools: No justice without trust.
International Journal of Educational Management, 18(4), 250-259.

[16] Kaur, R. (2012). Transformational and transactional leadership behaviour in selected public and private sector banks in Chandigarh. International Journal of Engineering and Management, 2 (2), 126-133

[17] Koc, H., Kiliclar, A. \&Yazicioglu, I (2013). The analyzing leadership styles of turkish managers in the scope of the Blake and Mouton's managerial grid. Journal of Business and Social Science, 4 (11), 96107.

[18] Komives, S.R. (1991). Gender differences in the relationship of hall director's transformational and transactional leadership and achieving styles. Journal of College Student Development, 32, 155-165.

[19] Kotur, R. B. and Anbazhagan, S (2014).The Influence of Education and Work-Experience on the Leadership Styles. Journal of Business and Management, 16, (2), 103-110

[20] Masi, R. I. (2008). Further assessment of Bass's (1985) conceptualization of transactional and transformational leadership. Journal of Applied Psychology, 7, 23-28.

[21] Miller, D. T., Taylor, B. \& Buck, M. L. (1991). Gender gaps: Who needs to be explained? Journal of Personality and Social Psychology, 61(1), 5-12.

[22] Mohammed, A. K., Othman, J \&D'Silva, L. J. (2012).social demographic factors that influence transformational leadership styles among top management in selected organizations in Malaysia. Asian Social Scienc,; 8,(13), 51-58

[23] Northouse, P. (2004). Leadership: Theory and practice (3rd ed.). Thousand Oaks, CA: Sage.

[24] Ortyoyande, J. H (2012).The relationship between demographic factors and leader behaviour of department chair persons of colleges of education in Michigan. Retrieved from http://scholarworks.wmich.edu

[25] Otieno, M. (2016). Influence of demographic factors on women's participation in political leadership in Rongo Constituency, Migori County, Kenya. International Journal of Innovative Research \& Development, 5, (7), 29-32.

[26] Pastor, C. J. \& Mayo, M. (2006). Transformational and. transactional leadership: An examination of managerial cognition among Spanish upper enchelons. IE Working Paper, WP06.. 
[27] Rosener, J.B. (1990). Ways women lead. Harvard

Business Review, (November/December), $\quad 119$ -

125.

[28] Talbert, J.E. \&Milbrey, W.M. (1994).Teacher professionalism in local school contexts.American Journal of Education, 102(2): 123-153

[29] Taylor, E.W. (1998). Transformative learning: A critical review. ERIC Clearinghouse on Adult, Career, \& Vocational Education

[30] Tejeda, M. J., Scandura, T. A., \&Pillai, R. (2001). The MLQ revisited: Psychometric properties and recommendations. The Leadership Quarterly, 12, 3152.

[31] Thompson, M.D. (2000). Gender, leadership orientation and effectiveness: Testing the theoretical models of Bolman Deal and Quinn. Sex Roles, 42(1), 969-992.

[32] Vecchio, R. P., \& Boatwright, K. J. (2002).Preferences for idealized styles of supervision. Leadership Quarterly, 13, 327-342. 